\title{
ANALISA PENGARUH FAMILY TYPES, FAMILY STAGES, DAN HOUSEHOLD CONFLICT TERHADAP PENGAMBILAN KEPUTUSAN PEMBELIAN MOBIL KELUARGA
}

\author{
Edwin Japarianto \\ Fakultas Ekonomi, Universitas Kristen Petra, Surabaya \\ E-mail: edwinj@petra.ac.id
}

\begin{abstract}
Abstrak: Penelitian membahas family types, family stages, dan household conflict pengaruhnya terhadap pengambilan keputusan pembelian mobil keluarga di Surabaya. Sampel penelitian ini berjumlah 100 responden dari pasangan suami-istri yang tinggal di Surabaya dan berminat membeli mobil keluarga. Pengukuran dilakuan dari variable family types (XI) dengan indikator nuclear family dan exended family, variable family stages (X2) dengan indikator joint, wife dominant, husband dominant dan variabel household conflict (X3) dengan indikator consensual purchase decision, accomodarive purchase decision sebagai variable independen sedangkan pengambilan keputusan (Y) sebagai variable dependen, hasil penelitian menunjukkan: (1) variable X1 memiliki pengaruh positif terhadap keputusan pembelian; (2) variable X2 memiliki pengaruh positif terhadap keputusan pembelian; (3) variable X3 memiliki pengaruh positif terhadap keputusan pembelian dan variable $\mathrm{X} 2$ memiliki pengaruh paling besar.
\end{abstract}

Kata kunci: Family types; family stages; household conflict; pengambilan keputusan.

\begin{abstract}
The study discusses family types, family stages, and household conflict effects on decision making of family car purchase in Surabaya. The sample of this study amounted to 100 respondents from married couples who live in Surabaya and are interested in buying a family car. Measurements were taken from family types (X1) variabls with indicators of nuclear family and exended family, family stages (X2) variable with indicator joint, wife dominant, husband dominant and household conflict variable (X3) with indicator consensual purchase decision, accomodarive purchase decision as variable Independent while decision making (Y) as a dependent variable, the results showed: (1) variable X1 has a positive influence on purchasing decisions; (2) variable X2 has a positive influence on purchasing decision; (3) variable X3 has a positive influence on purchase decision and variable $X 2$ has the biggest influence.
\end{abstract}

Keywords: Family types; family stages; household conflict; buying decision making.

\section{PENDAHULUAN}

Transportasi adalah pemindahan manusia atau barang dari satu ke tempat lainnya dengan menggunakan sebuah alat yang bisa digerakkan oleh manusia atau mesin. Sistem transportasi merupakan bagian penting dalam suatu kota. Kota yang berkembang akan sangat membutuhkan akses transporttasi. Jika tidak dilakukan pengelolaan yang baik dan serius, maka masalah-masalah yang timbul dari transportasi ini akan sangat menguras energi dan biaya. Adapun transportasi dibagi menjadi 3 jenis yaitu transportasi darat, air dan udara, sedangkan yang paling sering digunakan adalah transportasi darat.

Pada zaman dahulu transportasi darat yang sering digunakan adalah sepeda, becak, bajaj, bemo, helicak dan delman, namun seiring dengan perbaikan sarana dan prasarana transportasi di Indonesia, masyarakat mengharapkan adanya alat transportasi yang lebih nyaman dan cepat. Maka pada era modern ini, transportasi darat yang sering digunakan adalah kendaraan bermotor baik yang beroda dua maupun empat. Selain transportasi umum, masyarakat Indo- nesia juga menggunakan mobil pribadi sebagai alat transportasinya. Penggunaan kendaraan pribadi didorong dengan tingginya aktivitas masyarakat dan juga ketidakpuasan terhadap transportasi umum yang ada. Untuk itu para produsen mobil berlomba-lomba menawarkan produk yang mampu menjawab kebutuhan pasar konsumen mobil pribadi.

Perkembangan industri mobil di Indonesia mengalami pertumbuhan yang baik. Hal ini dapat kita lihat dari peningkatan jumlah unit mobil yang terjual dari tahun ke tahun. Berdasarkan data pada tahun 2011 telah terjadi peningkatan penjualan sebesar 17\% bila dibandingkan dengan tahun 2010. Pada tahun 2012, penjualan mencapai rekor tertinggi dengan penjualan di atas 1 juta unit dan mengalami peningkatan sebesar 25\% dibandingkan dengan tahun sebelumnya (detikOto, 2012)

Konsumen keluarga yang membeli produk mobil keluarga di Surabaya cenderung membawa pasangannya ketika mengunjungi showroom maupun pameran untuk melihat produk. Pasangan dan anak seringkali juga memberikan pendapat baik mengenai tipe ataupun warna yang akan dipilih, namun di- 
karenakan mobil keluarga tidak termasuk produk baru sehingga pada umumnya mereka tidak lagi asing dengan spesifikasi dari produk yang ditawarkan. Mereka sudah mengetahui spesifikasi dari keluarga dan orang-orang terdekat yang telah menggunakan produk tersebut.

Kurang lebih sebanyak $70 \%$ keputusan beli dilakukan oleh pihak suami dan sisanya diputuskan oleh pihak istri. Faktor yang menjadi pertimbangan konsumen dalam melakukan pembelian adalah harga yang ditawarkan, ketersediaan unit mobil, bonus yang diberikan, layanan purna jual, dan harga jual kembali produk tersebut. Karakteristik konsumen yang ada di Surabaya cenderung lebih teliti dan kritis ketika akan membeli produk mobil keluarga. Hal ini menyebabkan proses pengambilan keputusan membutuhkan waktu yang lebih lama.

Melihat realita ini dari berbagai aspek dan latar belakang di atas, maka peneliti memilih objek penelitian produk mobil keluarga. Melalui analisa pengaruh family types, family stages dan household conflict terhadap pengambilan keputusan pembelian pada produk mobil keluarga.

\section{LANDASAN TEORI}

\section{Grup}

Menurut Sciffman dan Kanuk (2007), grup adalah "two or more people who interact to accomplish either individual or mutual goals" atau dua atau lebih orang yang berinteraksi untuk mencapai tujuan individu atau kelompok. Kemudian kita juga mengenal istilah reference group yaitu kelompok yang dijadikan sebagai referensi ketika seseorang memutuskan untuk membeli atau mengkonsumsi suatu produk atau jasa.

Reference group ada 2 jenis yaitu Normative reference group dan Cooperative reference group. Normatice reference group adalah reference group yang mempengaruhi secara umum nilai-nilai dasar serta perilaku seseorang, misalnya keluarga. Sedangkan Comparative reference group adalah reference group yang berfungsi sebagai panutan mengenai sikap atau perilaku seseorang. Contohnya adalah cara hidup tetangga yang tampak mengagumkan dan layak ditiru seperti cara mereka merawat rumah dan sebagainya.

\section{Keluarga}

Menurut Sciffman \& Kanuk (2010, p.316), family atau keluarga adalah "two or more persons related by blood, marriage, or adoption who reside together" yaitu dua orang atau lebih yang berhubungan darah, dalam suatu pernikahan, atau diadopsi yang tinggal bersama-sama.

Keluarga dapat dikatakan rumah tangga, namun rumah tangga dapat terdiri dari keluarga maupun nonkeluarga. Menurut Sciffman \& Kanuk (2010, p. 306) keluarga mungkin adalah reference group yang memiliki kekuatan yang paling kuat untuk mempengaruhi perilaku konsumen.

\section{Family Types (Tipe Keluarga)} 477):

Ada dua tipe keluarga yaitu (Solomon, 2009, p.

\section{a. Nuclear family (keluarga inti)}

Keluarga yang terdiri dari ayah, ibu dan satu atau lebih anak. Jenis keluarga ini cenderung memiliki anggota keluarga yang lebih sedikit dibandingkan dengan extended family. Wewenang yang lebih besar dalam melakukan pengambilan keputusan biasanya pada nuclear family berada di tangan orang tua.Anak dapat melakukan pengambilan keputusan ketika anak tersebut sudah dewasa dan mampu untuk membuat keputusan.

b. Extended family

Keluarga yang terdiri dari tiga generasi dan tinggal bersama yang biasanya terdiri dari kakek, nenek, paman, bibi dan keponakan. Pola konsumsi extended family tentunya tidak sama dengan nuclear family, dikarenakan jumlah anggota yang ada di rumah tersebut lebih banyak. Pada saat akan membeli suatu produk tentunya pertimbangan yang dilakukan akan lebih banyak.

\section{Family Stages}

Dalam satu rumah tangga biasanya dimulai dengan hubungan pernikahan antara suami dan istri, hal ini menyebabkan marketer tertarik untuk melihat pengaruh mereka dalam pengambilan keputusan konsumsi barang dan jasa.Pengaruh tersebut dapat diklasifikasikan menjadi 4 jenis, yaitu (Sciffman \& Kanuk, 2010, p. 330):

a. Joint (setara antara suami dan istri) pembelian yang keputusannya dilakukan bersama adalah produk seperti rumah, furnitur ruang keluarga dan liburan.

b. Wife dominated (istri dominan)

Biasanya pembelian produk yang keputusannya didominasi oleh istri adalah pembelian alat rumah tangga, makanan, dan perlengkapan dapur.

c. Husband dominated (suami dominan)

Biasanya pembelian produk yang keputusannya didominasi oleh suami adalah pembelian mobil, minuman keras, dan asuransi kesehatan. 
d. Autonomic (keputusan sepihak atau soliter)

Keputusan yang dibuat perorangan baik suami atau istri saja tanpa menanyakan pendapat dari pasangannya.

\section{Household Conflict}

Proses pengambilan keputusan keluarga dalam rumah tangga, sama seperti konfrensi bisnis. Setiap anggota keluarga memiliki aktivitas dan prioritas yang berbeda-beda, sehingga memungkinkan untuk terjadi perebutan kekuasaan untuk bersaing dalam setiap intrik permasalahan yang ada. Ada 2 tipe dasar pengambilan keputusan dalam keluarga (Solomon, 2009, p. 484):

a. Consencual purchase decision

Anggota keluarga setuju pada pembelian yang akan dilakukan, yang membedakan adalah bagaimana cara untuk mencapai hal tersebut.

b. Accomodative purchase decision

Anggota keluarga memilki preferensi dan prioritas yang berbeda namun mereka setuju pada pembelian yang akan dilakukan.

\section{Keputusan Pembelian}

Pada akhirnya yang menjadi tujuan akhir dari seluruh strategi pemasaran adalah konsumen memilih produknya ketika mengambil keputusan beli. Keputusan pembelian menurut (Blackwell \& Miniard, 2006, p. 210) adalah "the selection of an option from two or alternative choice". Jadi, keputusan pembelian adalah suatu keputusan seseorang dimana individu tersebut memilih salah satu dari beberapa alteratif yang dimilikinya.

\section{Penelitian Terdahulu}

Pada penelitian sebelumnya yang dilakukan oleh Viesturs Uzulens (2012) dengan judul “Joint-Decision Making Roles Between Spouses in Latvia When Buying A Family Car", peneliti meneliti bagaimana pasangan suami istri di Latvia mengambil keputusan beli mobil ditinjau dari perspektif teoritis serta meneliti peran antara suami istri. Kesimpulannya adalah proses pengambilan keputusan dapat dibagi menjadi faktor individu, keluarga, dan faktor lain. Banyak keputusan diambil bersama apabila pasangan memiliki pandangan yang sama mengenai kesetaraan derajat antara suami istri dan level pendidikan yang sama. Apabila pernah ada konflik dengan orang tua, hanya salah satu pasangan yang tertarik terhadap produk, atau berkontribusi lebih besar mengenai anggaran rumah tangga, keputusan cenderung dilaku- kan secara soliter.Penelitian menunjukkan bahwa peran suami dalam pembelian mobil lebih besar dibandingkan istri.Tahap pencarian informasi didominasi oleh pihak suami, sehingga hal ini mengindikasikan pihak suami yang menjadi target marketer.Penerapan strategi pemasaran yang dilakukan harus seimbang antara suami dan istri karena besarnya uang yang dikeluarkan untuk membeli mobil merupakan keputusan bersama.

\section{Kerangka Konseptual}

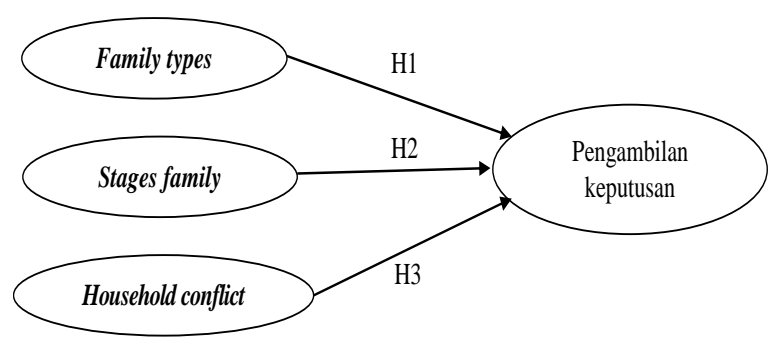

Gambar 1. Kerangka Konseptual

\section{Hipotesa}

$\mathrm{H}_{1}$ : Family types berpengaruh secara positif terhadap keputusan pembelian.

$\mathrm{H}_{2}$ : Family stages berpengaruh secara positif terhadap keputusan pembelian.

$\mathrm{H}_{3}$ : Household conflict berpengaruh secara positif terhadap keputusan pembelian.

\section{METODE PENELITIAN}

\section{Populasi}

Populasi adalah kelompok elemen yang lengkap yang biasaya berupa orang, obyek, transaksi atau kejadian dimana peneliti tertarik untuk mempelajarinya atau menjadi obyek penelitian (Kuncoro, 2003, p.103). Dalam penelitian ini populasinya adalah seluruh pasangan suami-istri yang tinggal di Surabaya dan berminat membeli mobil keluarga.

\section{Sampel}

Sampel adalah bagian dari jumlah dan karakteristik yang dimiliki oleh populasi tersebut (Sugiyono, 2010). Teknik yang dipilih adalah purposive sampling yaitu penarikan sampel berdasarkan kriteria tertentu yang telah ditetapkan peniliti dengan mengasumsikan populasi tidak terbatas. Adapun sampel yang dipilih adalah pasangan suami istri yang telah melakukan pembelian mobil keluarga. 


\section{Definisi Operasional Variabel}

\section{Family Types $(\mathrm{X})$}

a. Nuclear Family (X1); di ukur melalui kontribusi pasangan, pendapat anak dan pendapat diri sendiri

b. Extended Family (X2); di ukur melalui pendapat orang tua dan sanak saudara

2. Family Stages $(\mathrm{X})$

a. Joint (X3); di ukur dari semua keputusan dan inisiatif bersama

b. Wife Dominated (X4); di ukur dari pendapat dan insiaiatif istri

c. Husband Dominated (X5); di ukur dari pendapat dan inisiatif suami

d. Autonomic (X6); di ukur dari pendapat dan inisiatif langsung tanpa melibatkan pasangan

3. Household Conflict (X)

a. Consensual Purchase Decision (X7); di ukur melalui kesamaan pandangan pasangan dan penyelesaiannya

b. Accomodative Purchase Decision (X8); di ukur melalui keberbedaan pandangan pasangan dan penyelesaiannya

4. Variabel endogen keputusan pembelian (Y)

Variabel Y dalam penelitian ini adalah keputusan pembelian dimana konsumenmemilih dari beberapa alternatif yang dimiliki.

\section{Alat analisa}

\section{Customer Satisfaction Index (CSI) dan Customer Dissatisfaction Index (CDI)}

Customer satisfaction index merupakan indeks untuk menentukan tingkat kepuasan pelanggan secara menyeluruh dengan pendekatan yang mempertimbangkan tingkat kepentingan dari atribut-atribut yang diukur. Dalam penelitian ini, penulis menggunakan metode two boxes yaitu jumlah responden yang memberikan jawaban setuju atau sangat setuju. Sedangkan customer dissatisfaction index adalah indeks yang menentukan tingkat ketidakpuasan pelanggan secara menyeluruh.

\section{Analisa Regresi Linear Berganda (Multiple regres- sion analysis)}

Analisis regresi linier berganda adalah hubungan secara linear antara dua atau lebih variabel independen dengan variabel dependen. Analisis ini digunakan untuk mengetahui arah hubungan antara variabel independen dengan variabel dependen apakah masing-masing variabel independen berhubungan positif atau negatif dan untuk memprediksi nilai dari variabel dependen apabila nilai variabel independen mengalami kenaikan atau penurunan.

\section{ANALISA DAN PEMBAHASAN}

Berikut adalah nilai rata-rata jawaban responden mengenai dimensi nuclear family (X1), extended family (X2), Stages Family yang terdiri dari joint (X3), wife dominanted (X4), husband dominanted (X5), autonomic (X6), Household Conflict yang terdiri dari consensual purchase decision (X7) dan accommodative purchase decision $(\mathrm{X} 8)$ :

Tabel 1. Hasil Analisa Rata-Rata Top Two Boxes dan Bottom Two Boxes

\begin{tabular}{|c|c|c|}
\hline \multirow[t]{2}{*}{ Dimensi } & \multicolumn{2}{|c|}{$\begin{array}{cc}\text { Top Two } & \text { Bottom } \\
\text { Boxes } & \text { Two Boxes } \\
(\%) & (\%) \\
\end{array}$} \\
\hline & Top & Bottom \\
\hline Nuclear Family (XI) & 72.0 & 28.0 \\
\hline Extended Family (X2) & 34.5 & 65.5 \\
\hline Joint (X3) & 95.0 & 5.0 \\
\hline Wife Dominant (X4) & 25.0 & 75.0 \\
\hline Husband Dominant (X5) & 70.0 & 30.0 \\
\hline Autonomic (X6) & 41.0 & 59.0 \\
\hline Consencual Purchase Decision (X7) & 71.7 & 28.3 \\
\hline Accomodative Purchase Decision (X8) & 33.5 & 66.5 \\
\hline
\end{tabular}

Tabel di atas menunjukkan bahwa dimensi yang memiliki penilaian CSI paling tinggi dari responden adalah joint (95\%), hal ini sesuai dengan kebiasaan orang Indonesia yang cenderung melakukan diskusi untuk mencari solusi atas permasalahan yang terjadi. Sedangkan dimensi yang memiliki penilaian CSI paling rendah dari responden adalah wife dominant (25\%). Beberapa responden menyatakan pihak istri kurang paham mengenai mobil baik mengenai spesifikasi, perawatan dan fitur yang ada.Selain itu pihak istri biasanya hanya memandang mobil sebagai alat transporatasi saja, sehingga yang biasanya menjadi perhatian oleh istri hanyalah sisi kenyamanan dan kepraktisan mengendarai mobil tersebut. Berbeda dengan suami yang lebih memperhatikan banyak aspek seperti fitur, warna cat yang lebih mudah dirawat, kemudahan mendapatkan suku cadang, pelayanan setelah pembelian dan lain sebagainya.

Mayoritas responden setuju untuk memperhatikan kebutuhan serta pendapat dari keluarga intinya. Hal ini sesuai dengan nilai yang ingin ditonjolkan dari mobil keluarga di mana mobil tersebut ditujukan kepada konsumen yang berkeluarga. Selain itu seperti yang kita ketahui bahwa masyarakat Indonesia menjunjung tinggi kekeluargaan sehingga tentunya ketika akan membeli mobil akan melakukan diskusi dengan keluarga intinya. Sedangkan responden 
kurang setuju dalam memperhatikan kebutuhan serta pendapat dari sanak saudara dan kerabat dikarenakan mobil keluarga tersebut pada umumnya digunakan oleh keluarga inti mereka saja.

Mayoritas responden setuju untuk melakukan diskusi serta mengambil keputusannya bersama dengan pasangan dikarenakan produk yang dibeli berupa mobil dan membutuhkan dana yang cukup besar sehingga responden cenderung akan berdiskusi dengan pasangannya baik dari segi tipe serta spesifikasi mobil keluarga yang akan dibeli maupun cara pembayaran yang akan dipilih. Selain itu sesuai dengan value dari produk ini yang mengedepankan penggunaannya bersama keluarga menyebabkan responden menanyakan pendapat dari anggota keluarganya terutama mengenai kenyamanan serta keamanan berkendara bagi keluarga. Adapun hal lainyang menjadi topik diskusi responden dengan pasangannya adalah kemudahan penggunaan. Beberapa responden menggunakan mobil keluarga untuk kebutuhan operasional keluarganya seperti mengantar dan menjemput anak ke sekolah, dan pihak yang biasanya bertanggung jawab terhadap hal ini adalah pihak istri. Oleh karena itu pihak suami juga menanyakan kepada istri mengenai kemudahan istri untuk mengendarai mobil keluarga tersebut. Salah satu contohnya dengan memilih mobil keluarga bertransmisi automatic yang lebih mudah dikendarai.

Responden kurang setuju apabila keputusan pembelian mobil keluarga didominasi oleh istri. Sebaliknya responden setuju apabila keputusan pembelian mobil keluarga didominasi oleh suami. Hal ini dikarenakan pria atau pihak suami lebih mengerti mengenai spesifikasi dari mobil dibanding dengan istrinya. Selain itu pada umumnya yang mengurus perawatan mobil nantinya adalah pihak suami sehingga istri biasanya hanya mendengarkan dan mengikuti apa yang menjadi pilihan dari pasangannya.

Selain itu responden kurang setuju apabila keputusan pembelian mobil keluarga dilakukan individual oleh suami atau istri saja, dikarenakan produknya yaitu mobil dan tentunya membutuhkan dana yang cukup besar sehingga pada umumnya responden akan berdiskusi dengan pasangannya. Pengeluaran dana yang cukup besar ini juga biasanya membuat responden tidak secara langsung memutuskan membeli Mobil keluarga pada saat itu juga. Sebelum melakukan pembelian, responden akan mengambil waktu yang cukup lama untuk mendapatkan informasi yang dibutuhkan baik mengenai fitur, tipe, harga, kemudahan perawatan, harga purna jual dan sebagainya. Responden akan menanyakan pendapat pada pihak yang dianggap memiliki pengetahuan yang dibutuhkannya, sekalipun istri belum tentu memiliki pengetahuan yang ditujukan, namun dikarenakan penggunaan mobil tersebut digunakan bersama-sama dengan keluarga maka pihak suami cenderung berdiskusi dengan pasangannya dalam mengambil keputusan pembelian mobil keluarga.

Responden menyatakan setuju apabila mereka sepakat untuk membeli mobil keluarga sekalipun ada perbedaan pendapat mengenai lokasi pembelian ataupun metode pembayaran yang akan digunakan. Berdasar dimenri consencual purchase decision Sedangkan responden menyatakan kurang setuju apabila ada perbedaan pendapat mengenai tipe serta harga mobil keluarga yang dibeli. Pada dimensi accomodative purchase decision menyatakan bahwa pihak istri biasanya kurang paham mengenai perbedaan setiap tipe mobil keluarga yang ditawarkan sehingga mereka biasanya menyerahkan pilihan kepada suaminya, karena dirasa pihak suami lebih paham mengenai kelebihan dan kekurangan dari tipe mobil keluarga yang dipilih.

\section{Analisis Regresi Linier Berganda}

Berikut ini adalah hasil analisis regresi linier berganda antara dimensi family types yang terdiri dari nuclear family (X1), extended family (X2), Stages Family yang terdiri dari joint (X3), wife dominanted (X4), husband dominanted (X5), autonomic (X6), Household Conflict yang terdiri dari consensual purchase decision (X7) dan accommodative purchase decision (X8) terhadap Keputusan pembelian mobil keluarga.

Model regresi linier berganda dalam penelitian ini adalah:

$\mathrm{Y}=4,5+0,102$ Nuclear Family + 0,010 Extended Family + 0,119Joint + 0,082 Wife Dominant + 0,163 Husband Dominant + 0,012 Autonomic+ 0,113 Consencual Purchase Decision - 0,059 Accomodative Purchase Decision:

a. Nilai Koefisien Korelasi (R)

Koefisien korelasi (R) sebesar 0,840 menunjukkan bahwa hubungan variabel bebas Family, Stages Family, Household Conflict terhadap Keputusan pembelian mobil keluarga adalah cukup kuat.

b. Nilai Koefisien Determinasi (R-Square)

koefisien determinasi ( $R$-Square) yang diperoleh adalah 0,709, memiliki arti bahwa keputusan pembelian mobil keluarga dijelaskan oleh variable bebas sevesar 70,9\% dan sisanya yaitu 39,1\% dijelaskan oleh faktor lain yang tidak dimasukkan ke dalam variabel penelitian.

c. Uji Hipotesis Pengaruh Simultan (Uji F)

Berdasarkan analisis regresi linier berganda, dapat dilihat bahwa nilai signifikansi uji $\mathrm{F}$ adalah nol atau kurang dari $0.05(\alpha=5 \%)$, maka dapat disim- 
pulkan bahwa variabel bebas Family Types, Stages Family Household Conflict secara bersama-sama berpengaruh signifikan terhadap keputusan pembelian mobil keluarga.

d. Uji Hipotesis Pengaruh Parsial (Uji t).

Dari tabel 1 dapat diperoleh penjalan hasil uji t sebagai berikut:

\section{Dimensi Family Types}

Nuclear family mempunyai t hitung sebesar 2.385 lebih besar dari $t$ tabel 1.986, dengan nilai signifikansi 0.019 kurang dari sama dengan 0.05, maka $\mathrm{H}_{0}$ ditolak dan $\mathrm{H}_{\mathrm{a}}$ diterima. Berdasarkan hasil ini dapat disimpulkan bahwa nuclear family berpengaruh secara signifikan terhadap keputusan pembelian mobil keluarga. Koefisien regresi nuclear family sebesar 0.102 menunjukkan bahwa dimensi ini mempunyai arah pengaruh positif terhadap pengambilan keputusan mobil keluarga. Hal ini berarti apabila semakin tingginya perhatian konsumen terhadap kebutuhan serta pendapat dari keluarga inti akan meningkatkan keputusan pembelian mobil keluarga. Berdasarkan wawancara dengan responden, mereka menyatakan bahwa hal yang terpenting dalam pembelian mobil keluarga adalah kenyamanan seluruh anggota keluarga dalam menggunakan mobil tersebut. Hal ini menyebabkan purchaser yang biasanya adalah orang tua baik istri atau suami menanyakan pendapat dari keluarganya ketika akan membeli mobil tersebut.

Extended family mempunyai $\mathrm{t}$ hitung sebesar 0.232 lebih kecil dari t tabel 1.986, dengan nilai signifikansi 0.817 lebih besar dari 0.05 , maka $\mathrm{H}_{0}$ diterima dan $\mathrm{H}_{\mathrm{a}}$ ditolak. Berdasarkan hasil ini dapat disimpulkan bahwa extended family tidak berpengaruh secara signifikan terhadap keputusan pembelian mobil keluarga. Berdasarkan hasil pengujian diatas, hipotesis penelitian yang menduga bahwa dimensi pada dimensi family types secara parsial berpengaruh secara signifikan terhadap keputusan pembelian, hanya terbukti pada nuclear family, sedangkan pada extended family tidak terbukti. Kemudian peneliti melakukan wawancara dengan beberapa responden untuk mencari tahu mengapa extended family tidak berpengaruh. Dan didapati bahwa dalam melakukan pembelian mobil keluarga, responden kurang memperhatikan pendapat serta kebutuhan sanak saudaranya. Hal ini disebabkan karena mobil keluarga yang akan dibeli lebih banyak digunakan oleh anggota keluarga inti sehingga yang lebih diutamakan adalah pendapat serta kebutuhan dari keluarga inti tersebut.

\section{Dimensi Family Stages}

Joint mempunyai t hitung sebesar 2.784 lebih besar dari t tabel 1.986, dengan nilai signifikansi 0.007 kurang dari sama dengan 0.05 , maka $\mathrm{H}_{0}$ ditolak dan $\mathrm{H}_{\mathrm{a}}$ diterima. Berdasarkan hasil ini dapat disimpulkan bahwa joint berpengaruh secara signifikan terhadap keputusan pembelian mobil keluarga. Koefisien regresi joint sebesar 0.119 menunjukkan bahwa dimensi ini mempunyai arah pengaruh positif terhadap pengambilan keputusan mobil keluarga. Hal ini berarti apabila semakin banyak pasangan yang berdiskusi serta mengambil keputusan secara bersama-sama akan meningkatkan keputusan pembelian mobil keluarga. Hasil tersebut sesuai dengan pernyataan dari responden yang mengemukakan bahwa produk tersebut membutuhkan dana yang besar untuk membelinya sehingga tentunya mereka akan berdiskusi bersama dengan pasangannya terlebih dahulu sebelum melakukan pembelian.

Wife dominant mempunyai thitung sebesar 1.987 lebih besar dari t tabel 1.986, dengan nilai signifikansi 0.050 kurang dari sama dengan 0.05 , maka $\mathrm{H}_{0}$ ditolak dan $\mathrm{H}_{\mathrm{a}}$ diterima. Berdasarkan hasil ini dapat disimpulkan bahwa wife dominant berpengaruh secara signifikan terhadap keputusan pembelian mobil keluarga. Koefisien regresi wife dominant sebesar 0.082 menunjukkan bahwa dimensi ini mempunyai arah pengaruh positif terhadap pengambilan keputusan mobil keluarga. Hal ini berarti apabila jumlah dominasi pihak istri dalam pengambilan keputusan semakin tinggi akan meningkatkan keputusan pembelian mobil keluarga.

Husband dominant mempunyai t hitung sebesar 3.887 lebih besar dari t tabel 1.986, dengan nilai signifikansi 0.000 kurang dari sama dengan 0.05, maka $\mathrm{H}_{0}$ ditolak dan $\mathrm{H}_{\mathrm{a}}$ diterima. Berdasarkan hasil ini dapat disimpulkan bahwa husband dominant berpengaruh secara signifikan terhadap keputusan pembelian mobil keluarga. Koefisien regresi husband dominant sebesar 0.163 menunjukkan bahwa dimensi ini mempunyai arah pengaruh positif terhadap pengambilan keputusan mobil keluarga. Hal ini berarti apabila jumlah dominasi pihak suami dalam pengambilan keputusan semakin tinggi akan meningkatkan keputusan pembelian mobil keluarga.

Dari hasil di atas, kita dapat melihat peran suami dalam melakukan pembelian mobil keluarga lebih besar dibanding pihak istri dikarenakan pihak suami lebih mengerti mengenai spesifikasi yang ditawarkan sedangkan pihak istri hanya mementingkan sisi kenyamanan, kepraktisan dan kemudahan serta keamanan dalam mengendarai mobil. 
Autonomic mempunyai t hitung sebesar 0.283 lebih kecil dari $\mathrm{t}$ tabel 1.986, dengan nilai signifikansi 0.778 lebih besar dari 0.05 , maka $\mathrm{H}_{0}$ diterima dan $\mathrm{H}_{\mathrm{a}}$ ditolak. Berdasarkan hasil ini dapat disimpulkan bahwa autonomic tidak berpengaruh secara signifikan terhadap keputusan pembelian mobil keluarga. Berdasarkan hasil pengujian diatas, hipotesis penelitian yang menduga bahwa dimensi pada dimensi family stages secara parsial berpengaruh secara signifikan terhadap keputusan pembelian, hanya terbukti pada joint, wife dominant dan husband dominant, sedangkan pada autonomic tidak terbukti. Berdasarkan hasil wawancara dengan beberapa responden didapati bahwa dalam melakukan pembelian mobil keluarga, responden cenderung berdiskusi serta mengambil keputusan pembelian secara bersama-sama dengan pasangannya sekalipun dalam keputusan tersebut dapat didominasi oleh salah satu pihak suami atau istri ataupun seimbang antara keduanya.

3. Dimensi Household Conflict

Consencual purchase decision mempunyai $\mathrm{t}$ hitung sebesar 2.662 lebih besar dari t tabel 1.986, dengan nilai signifikansi 0.009 kurang dari sama dengan 0.05, maka $\mathrm{H}_{0}$ ditolak dan $\mathrm{H}_{\mathrm{a}}$ diterima. Berdasarkan hasil ini dapat disimpulkan bahwa consencual purchase decision berpengaruh secara signifikan terhadap keputusan pembelian mobil keluarga. Koefisien regresi consencual purchase decision sebesar 0.113 menunjukkan bahwa dimensi ini mempunyai arah pengaruh positif terhadap pengambilan keputusan mobil keluarga. Hal ini berarti apabila perbedaan pandangan dalam hal metode pembayaran maupun lokasi pembelian semakin tinggi maka keputusan pembelian mobil keluarga akan semakin tinggi juga. Hal ini disebabkan pada awal mula respoden telah sepakat untuk membeli mobil keluarga, namun dalam proses diskusi sekalipun terjadi perbedaan pandangan mengenai lokasi maupun metode pembayaran yang akan digunakan, hal tersebut tidak mengubah keputusan semula untuk membeli mobil keluarga tersebut.

Accomodative purchase decision mempunyai $\mathrm{t}$ hitung sebesar -1.425 lebih kecil dari $t$ tabel 1.986, dengan nilai signifikansi 0.158 lebih besar dari 0.05 , maka $\mathrm{H}_{0}$ diterima dan $\mathrm{H}_{\mathrm{a}}$ ditolak. Berdasarkan hasil ini dapat disimpulkan bahwa accomodative purchase decision tidak berpengaruh secara signifikan terhadap keputusan pembelian mobil keluarga.

Berdasarkan hasil pengujian diatas, hipotesis penelitian yang menduga bahwa dimensi pada dimensi household conflict secara parsial berpengaruh secara signifikan terhadap keputusan pembelian, hanya terbukti pada consencual purchase decision sedangkan pada accommodative purchase decision tidak terbukti. Berdasarkan hasil wawancara dengan beberapa responden didapati bahwa ketika mengambil keputusan pembelian, responden cenderung memiliki pandangan serta keinginan yang sama misalnya responden memilih untuk membeli mobil keluarga tipe $\mathrm{G}$ dikarenakan keduanya melihat populasi dari tipe tersebut paling banyak dibeli oleh konsumen, sehingga tidak terjadi perbedaan pendapat mengenai tipe serta harga mobil keluarga yang ingin dibeli. Selain itu mereka juga cenderung mengikuti rekomendasi dari wiraniaga mengenai mobil yang akan dibeli.

Berdasarkan hasil t hitung didapati dimensi yang paling berpengaruh terhadap keputusan pembelian mobil keluarga adalah husband dominant (X5) karena t hitung-nya paling besar yaitu 3.887. Berdasarkan dengan hasil wawancara dengan beberapa responden ditemukan bahwa inisiatif untuk membeli mobil keluarga kebanyakan berasal dari pihak suami.Selain itu, pihak istri cenderung kurang paham mengenai perbedaan spesifikasi mobil keluarga yang ditawarkan sehingga istri menyerahkan pilihan tipe mobil kepada suami.

\section{KESIMPULAN DAN SARAN}

\section{Kesimpulan}

Berdasarkan hasil yang didapatkan kesimpulan yang dapat diambil yaitu: nuclear family berpengaruh secara positif dan signifikan secara parsial terhadap pengambilan keputusan pembelian mobil keluarga. Pengambilan keputussan di lakukan bersama sama dengan mempertimbangkan masukan dan pendapat dari masing masing pasangan tanpa intimidasi, hanya masing masing berpendapat sesuai perannya. Mencari kesamaan pendapat untuk memutusan pembelian mobil keluarga. Secara keseluruhan suami berperan lebih dominan sebagai kepala keluarga

\section{Saran}

Berdasarkan hasil penelitian yang didapatkan diberikan saran untuk perbaikan sebagai berikut:

1. Konsumen mobil keluarga sangat memperhatikan pendapat dari keluarga intinya. Oleh karena itu, penulis merasa bahwa perusahaan dapat membuat iklan komersial baik iklan untuk televisi yang berupa video, billboard, maupun iklan di media sosial seperti Youtube. 
2. Selain dengan menggunakan iklan, perusahaan dapat melakukan strategi promosi yang dapat meningkatkan kebersamaan keluarga yang berkaitan dengan mobil keluarga. Misalnya untuk pembelian selama periode bulan Juni hingga Agustus akan mendapatkan voucher menginap di resort selama 2 malam bersama keluarga.

\section{DAFTAR PUSTAKA}

"Penjualan Mobil 2012 Cetak Rekor Tertinggi." Muhammad Ikhsan. 2013. 14 Januari 2013. <www.oto.detik.com>

Blackwell, R.D, Engel, J.F, \& Miniard, P.W. (2006). Consumer Behavior, $10^{\text {th }}$ ed. Canada: Thomson South Western.

Kuncoro, M. (2003). Metode Riset untuk Bisnis dan Ekonomi. Jakarta: Erlangga.
J. Linchosten dan Mansyur. (1983). Pengantar Ilmu Jiwa Fenomenologi. Bandung: Jemmars.

Sciffman, L.G, Kanuk, L.L. (2007). Consumer Behavior, $9^{\text {th }}$ ed. New Jersey: Pearson Prentice Hall

Sciffman, L.G, Kanuk, L.L. (2010). Consumer Behavior, $10^{\text {th }}$ ed. New Jersey: Pearson Prentice Hall

Solomon, M.R. (2009). Consumer Behavior: Buying, Having, and Being, $8^{\text {th }}$ ed. New Jersey: Pearson Prentice Hall

Sugiyono (2010). Metode Penelitian Bisnis: Pendekatan Kuantitatif, Kualitatif dan $R \& D$. Bandung: Alfabeta

Uzulens, Viesturs. (2012) "Joint Decision-making Roles Between Spouses in Latvia When Buying a Family Car" BSc in Business. VU84938. April 2012 <www.pure.au.dk.com> 